\title{
MUSIK REBANA TERBANG KENCER SEBAGAI IRINGAN KESENIAN TRADISIONAL KUDA LUMPING
}

\author{
Bowo Laksono ${ }^{1}$, Suharto ${ }^{2}$, Bagus Susetyo ${ }^{3}$ \\ ${ }^{I}$ Mahasiswa Jurusan Sendratasik Universitas Negeri Semarang Indonesia \\ ${ }^{2,3}$ Dosen Jurusan Sendratasik Universitas Negeri Semarang Indonesia \\ Pendidikan Seni Musik, Universitas Negeri Semarang \\ Email: wilaksonobowo@yahoo.com
}

\begin{abstract}
Abstrak: Peneliti membuat rumusan masalah yang dapat dikaji dalam penelitian ini adalah "bagaimana bentuk pertunjukan musik rebana terbang kencer sebagai iringan kesenian tradisional Kuda Lumping di Dukuh Tegallaos, Desa Karang Jongkeng, Kecamatan Tonjong, Kabupaten Brebes. Tujuan dari penelitian ini adalah untuk mengetahui bentuk pertunjukan musik rebana terbang kencer sebagai iringan kesenian tradisional Kuda Lumping di Dukuh Tegallaos, Desa Karang Jongkeng, Kecamatan Tonjong Kabupaten Brebes. Penelitian ini menggunakan pendekatan kualitatif. Tehnik pengumpulan data meliputi observasi, wawancara, dan dokumentasi. Analisis data yang dilakukan menggunakan analisis data interaktif dari Miles dan Huberman. Hasil penelitian menunjukan bahwa bentuk pertunjukan kesenian tradisional Kuda Lumping dalam pementasanya dibagi atas tiga bagian pementasan, yaitu bagian pertama merupakan pembukaan, bagian kedua merupakan bagian inti, dan bagian ketiga merupakan bagian penutup. Bentuk pertunjukannya di kaji secara tekstual, yang terdiri dari bentuk komposisi dan bentuk penyajian.
\end{abstract}

Kata kunci: Bentuk Pertunjukan, Musik Pengiring, Kesenian Kuda Lumping, dan Rebana Terbang Kencer

\section{PENDAHULUAN}

Kesenian merupakan bagian dari unsurunsur kebudayaan yang merupakan sektor budaya yang dapat berperan menampilkan sosok wajah bangsa. Kebudayaan seni akan menyatu dengan sektor kebudayaan lainnya. Suatu kelompok masyarakat mempunyai jenis yang berbeda-beda, baik seni suara, seni rupa maupun seni gerak. Keadaan yang demikian akan memberikan warna, jenis, dan ciri khas daerah masing-masing.. Kebudayaan seni akan menyatu dengan sektor kebudayaan lainnya. Suatu kelompok masyarakat mempunyai jenis yang berbeda-beda, baik seni suara, seni rupa maupun seni gerak. Keadaan yang demikian akan memberikan warna, jenis, dan ciri khas daerah masing-masing. Di
Dukuh Tegallaos, Desa karang jongkeng, Kecamatan Tonjong

Kabupaten Brebes mempunyai kesenian yaitu Kesenian Kuda Lumping. Kesenian yang menggunakan terbang kencer sebagai pengiring musik dalam lagu.

Penelitian yang dilakukan oleh peneliti, yaitu menggunakan tinjauan pustaka dengan hasil penelitan-penelitian terdahulu. Penelitian yang digunakan oleh peneliti yaitu penelitan yang membahas tentang bentuk pertunjukan musik rebana sebagai iringan kesenian tradisional didaerahnya masingmasing. Hasil penelitian terdahulu hampir menyerupai dalam hal bentuk dan pertunjukannya, dalam hal ini peneliti melakukan penelitian yaitu bentuk musik rebana terbang kencer yang berfungsi sebagai pengiring kesenian tradisional. 
Beberapa tinjauan pustaka dari penelitian terdahulu yang dijadikan literatur adalah karya skripsi dari mahasiswa Universitas Negeri Semarang yang bernama Insani Yodha Negara (2009) yaitu yang berjudul "Bentuk dan fungsi pertunjukan musik terbang kencer dalam arak-arakan temanten tebu di Desa Pangkah Kecamatan Pangkah Kabupaten Tegal". Arak-arakan temanten tebu merupakan kesenian tradisional yang berfungsi sebagai upacara ritual yang dilaksanakan setahun sekali pada masa giling tebu. Dalam tradisi ini, masyarakat Desa Pangkah membuat kelompok musik yaitu kesenian terbang kencer yang pada awal tahun 2008 baru diresmikan, terbang kencer ini dalam arak-arakan temanten tebu berfungsi sebagai musik pengiring. Kesenian ini memiliki bentuk pertunjukan yang sederhana yaitu bentuk penyajian ensemble dari alat musik ritmis dengan seperangkat alat perkusi yang dilaksanakan dengan arak-arakan yang berjalan mengelilingi Desa Pangkah menelusuri rute yang telah ditentukan.

Skripsi yang menyangkut tentang pertunjukan juga pernah diteliti oleh Galuh Prestisa tahun (2013) yang berjudul "Bentuk pertunjukan dan nilai estetis kesenian terbang kencer pada grup Baitussolikhin di Desa Bumijawa Kecamatan Bumijawa Kabupaten Tegal". Berdasarkann hasil penelitian ini yang dikaji dalam bentuk pertunjukkanya dan nilai estetis syair lagu makhalul Qyam. Kesenian terbang kencer sangatlah unik karena kesenian terbang kencer berfungsi tidak hanya sebagai sarana hiburan tetapi sudah menjadi adat atau tradisi warga Desa Bumi Jawa. Berdasarka segi bentuk pertunjukkannya kesenian tradisional terbang kencer Baitussolikhin memiliki tiga urutan penyajian, tata panggung yang digunakan sangatlah sederhana tidak ada panggung yang khusus hanya tempat seadanya, formasi pemein menyesuaikan bentuk tempat atau panggung yang disediakan, tata busana yang dipakai yaitu hanyalah pakaian khas orang islam. Tata lampu yang digunakan yaitu lampu biasa pada malam hari. Tata suara yang disiapkan oleh panitia berupa mixer dan peralatan soundsistem lainnya. Nilai estetis yang terkandung dalam syair lagu yang berjudul makhalul qyam dari segi maknanya secara keseluruan berisi tentang puji-pujian yang ditujukan bagi Nabi Muhammad SAW, yang ditulis menggunakan beberapa gaya bahasa, dan termasuk dalam bentuk puisi bebas yang sejenis.

Dalam hal bentuk dan pertunjukan musik rebana juga pernah diteliti oleh Shofiyah Nurhdayati tahun 2015 yang berjudul "Bentuk Pertunjukan Kesenian Rebana Nurul Jannah di Desa Tireman Kecamatan Rembang Kabupaten Rembang". Grup rebana ini dalam bentuk modern adalah sebuah grup rebana yang beranggotakan ibuibu sudah sering tampil diacara hajatan bahkan sering mengikuti lomba tingkat kabupaten, dari hasil penelitiannya yaitu berdasarkan dari segi pertunjukan, Nurul Jannah memiliki urutan penyajian yang dilakukan oleeh MC grup Nuirul Jannah meliputi bagian awal, bagiann tengah dan bagian akhir, tata panggung yang digunakan adalah outdoor yang terletak diluar ruangan ataua panggung terbuaka, tata rias yang diapakai adalah tata rias korektif untuk tata keindahan. Tata lampu yang digunakan hanya lampu biasa pada malam hari kadang juga menggunakan lampu flood yang disediakan panitia setempat. Tata suara yang disiapkan oleh panitia berupa mixer dan peralatan sound system lainnya, yang terpenting jumlah microphone yang cukup akan menunjang kualitas suara dari grup Nurul Jannah. Lagulagu yang dibawakan oleh Nurul Jannah lebih bervariasi yaitu bukan hanya lagu sholawat saja, melainkan lagu-lagu khasidah asli yang disesuaikan dengan moment misalnya pada saat pembukaan dibuka dengan lagu bismillah, acara pernikahan dengan menyanyikan lagu pengantin baru dan juga lagu popular religi dan campur sari yang dapat dinikmati oleh semua kalangan masyarakat.

Jawa tengah sebagai wilayah yang memiliki keragaman budaya dan kekayaan kesenian tradisional rakyat, jawa tengah terdiri 
dari beberapa kota dan kabupaten setiap daerah mempunya kebudayaan dan kesenian tradisional yang beraneka ragam seperti halnya kabupaten Brebes, banyak kesenian yang ada salah satunya yaitu kesenian tradisional terbang kencer. Terbang adalah salah satu peralatan musik tradisional yang cukup dikenal oleh masyarakat kabupaten Brebes, khususnya masyarakat Tegallaos. Alat ini terbuat dari kayu yang dibentuk sedemikian rupa (melingkar), kemudian bagian permukaanya diberi kulit. Jadi, hampir serupa dengan bedug atau gendang. Bedanya, jika bedug badannya besar dan panjang, kemudian gendang badannya kecil dan sedikit panjang, tetapi terbang badannya sedang (lebih kecil dari bedug tetapi lebih besar dari gendang pada umumnya) dan pendek. Pada badan terbang ada tiga pasang logam (besi putih) yang oleh masyarakat setempat disebut kecrek atau genjring atau kencer, sehingga jika terbang tersebut dibunyikan, tidak hanya mengeluarkan suara yang berasal dari kulit, tetapi juga suara gembrinjing (gemerincing). Oleh karena itu, terbang tersebut dinamakan sebagai terbang kencer. Musik Rebana Terbang Kencer sampai sekarang Masih dilestarikan masyarakat Tegallaos sebagai pengiring dalam acara Maulud Nabi SAW, Khitanan, Khajatan, dan HUT RI. lagu yang dibawakan bukanlah lagu populer melainkan lagu yang sudah ada secara turun temurunn yang berisi tentang Sholawat dan sisindiran.

Menurut Bahasa Arab, musik Rebana atau Musik Sholawatan berasal dari kata asholat yang berarti do'a atau sembahyang ( Yunus dalam Sinaga, 2006:200). Sholawat adalah satu ungkapan yang penuh dengan nuansa-nuansa sastra yang berisi puji-pujian terhadap nabi Muhammad SAW.

Alasan yang melatar belakangi pengambilan judul serta mendorong penulis mengadakan penelitian terhadap masalah tersebut dikarenakan Musik iringan Kesenian Kuda Lumping yang biasanya menggunakan gamelan tetapi pada penelitian ini alat musik yang digunakan untuk mengiringi kesenian Kuda Lumping menggunakan Rebana
Terbang Kencer yang pada hakikatnya untuk menyebarkan Agama Islam oleh para wali sampai dengan sekarang menggunakan syairsyair bahasa arab, atau kitab berzanji.

Berdasarkan latar belakang yang telah dijabarkan diatas maka penulis tertarik mengadakan penelitian bentuk pertunjukan Kesenian Terbang Kencer grup paguyuban Kesenian kuda lumping Dukuh Tegallaos, Desa Karang Jongkeng, Kecamatan Tonjong, Kabupaten Brebes. Menurut Soedarsono (2003), mengatakan bahwa seni pertunjukan merupakan salah satu cabang seni yang selalu hadir dalam kehidupan masyarakat. Seni pertunjukan sebagai seni yang hilang dalam waktu, karena hanya bisa kita nikmati apabila seni tersebut sedang dipertunjukan.

Kajian yang difokuskan dalam penelitian ini pada bentuk seni pertunjukan secara tekstual. Menurut Susetyo (2009), aspek kajian bersifat tekstual yang dimaksud adalah hal-hal yang terdapat pada bentuk seni pertunjukan, saat disajikan secara utuh dan dinikmati langsung oleh masyarakat pendukungnya, yaitu bentuk komposisi dan bentuk penyajiannya. Bentuk komposisi suatu pertunjukan musik meliputi ritme, melodi, harmoni, struktur/bentuk lagu, syair, ekspresi, instrument, dan aransement. Sedangkan bentuk penyajian suatu pertunjukan musik meliputi urutan penyajian, tata panggung, tata rias, tata busana, tata suara, tata lampu, dan formasi.

Tujuan dari penelitian ini adalah untuk mengetahui bentuk pertunjukan musik rebana terbang kencer sebagai iringan kesenian tradisional Kuda Lumping di Dukuh Tegallaos, Desa Karang Jongkeng, Kecamatan Tonjong Kabupaten Brebes.

\section{METODE PENELITIAN}

Metode penelitian kualitatif adalah metode penelitian yang berlandaskan pada filsafat postpositivisme, digunakan untuk meneliti pada kondisi obyek yang alamiah, (sebagai lawannya adalah eksperimen) dimana peneliti adalah sebagai instrumen kunci, 
teknik pengumpulan data dilakukan secara triangulasi (gabungan), analisis data bersifat induktif atau kualitatif, dan hasil penelitian kualitatif lebih menekankan makna dari pada generalisasi (Sugiyono, 2011:9).

Penellitan kualitatif menurut Bogdan \& Taylor ( dalam Sumaryanto, 2014 : 14 ) merupakan prosedur penelitian yang menghasilkan data deskriptif berupa kata-kata tertulis atau lisan dari orang-orang dan perilaku yang dapat diamati. Dari teori di atas dapat diambil makna yaitu pedekatan kualitatif merupakan pendekatan yang dilakukan dalam penelitian hasil data yang diperoleh adalah kata-kata atau tulisan untuk menggambarkan suatu objek dengan kenyataan yang ada di lapangan.

Penelitian ini menggunakan jenis observasi langsung, yaitu pengamatan dan pencatatan yang dilakukan terhadap objek di tempat terjadi atau berlangsungnya peristiwa, sehingga peneliti berada bersama objek yang diselidiki. Jadi peneliti akan terjun langsung ke lapangan dan akan mengamati sendiri bagaimana pelaksanaan pembelajarannya. Teknik observasi tersebut dilaksanakan untuk mengetahui keadaan lingkungan sekolah, proses pelaksanaan pembelajaran drum band, serta kendala pelatih selama proses pembelajaran.

\section{HASIL PENELITIAN DAN PEMBAHASAN}

\section{Bentuk Pertunjukan Musik Rebana} Terbang Kencer Sebagai Iringan Kesenian Kuda Lumping Di Dukuh Tegallaos.

Bentuk dalam arti umum adalah wujud fisik yang nampak, sedangkan pertunjukan adalah segala sesuatu yang dipertontonkan, dipamerkan, dan didemonstrasikan kepada orang lain (Purwadarminta, 2003: 1086). Pada bentuk pertunjukan musik, musik merupakan pencerminan jiwa atau ide dalam bentuk nada-nada yang tertata harmoni (Bastomi 1992 : 55 ).

Aspek Komposisi Musik Pengiring Kesenian Tradisional Kuda Lumping
Irama musik yang dibawakan grup musik rebana terbang kencer dalam setiap pentasnya sering menggunakan irama sholawat dengan satu pola irama yang di ulang-ulang (Ostinato) sesuai kebutuhan dengan tempo sedang menggunakan birama 4/4, karena dengan tempo tersebut tidak terlalu cepat dan tidak terlalu lambat dalam memainkan sebuah lagu yang diiringi menggunakan irama sholawat. Rebana terbang kencer yang memegang peran penting terhadap irama adalah pukulan bedug, terbang kencer dalam paguyuban kuda lumping memiliki nama misan, mindo, mintelu, minpat, bedug.

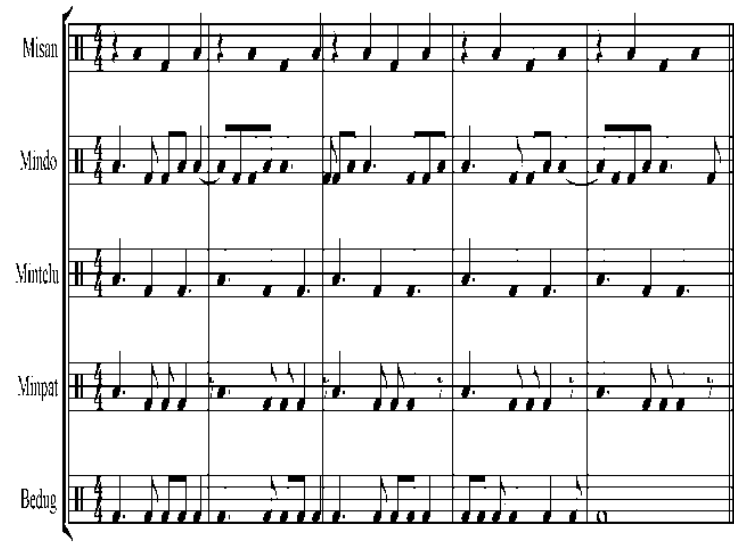

Dari ke empat alat musik yang di mainkan yaitu Misan, Mindo, Mintelu, Minpat, alat musik ini memainkan ritmis yang sudah di tentukan dalam notasi di atas. Sedangkan Bedug berfungsi sebagai pemegang peran terhadapat irama dari ke empat buah alat musik tersebut.

Melodi pada lagu-lagu kelompok terbang kencer Dukuh Tegallaos terletak pada vokal dan syair lagunya. Hal ini dikarenakan tidak adanya instrument bernada yang dipakai oleh kelompok musik Terbang Kencer Dukuh Tegallaos yaitu tangga nada mayor dan minor. karna dalam pertunjukanya menggunakan lagu-lagu atau syair yang berasal dari kitab albarzanji. Contohnya lagu dengan tangga nada mayor yaitu Sholawat Nabi.

Lagu Sholawat Nabi ini sering dibawakan oleh Grup Paguyuban Kesenian Kuda Lumping di Dukuh Tegallaos dalam mengiringi Kesenian Kuda Lumping. Melodi 
dalam lagu ini hanya di ulang-ulang sehingga memudahkan pemain atau vokal dalam membawakannya.

Teori harmoni yang di pakai yaitu menggunakan tehnik paradidlle yang ada pada tehnik perkusi atau drum pada umunya. pada tehnik ini ritmis yang dimainkan oleh rebana sama dengan tehnik paradidlle yaitu saling imbal-imbalan dalam memainkannya.

dengan instrument terbang kencer 3 (Mintelu) yang bermain secara imbal-imbalan dengan instrument terbang kencer 1 sehingga membentuk keselarasan suara yang di sebut harmoni suara. Perbedaan harmoni pada alat musik ritmis dengan alat musik bernada yaitu pada alat musik ritmis harmoni suara terletak pada pola ritmis yang di mainkan antara ritmis yang satu dengan ritmis yang lain. Yang dimainkan secara imbal-imbalan sehingga membentuk perpaduan suara yang harmonis. Tetapi pada harmoni alat musik bernada biasanya harmoni terletak pada nada-nada yang sama atau pada akor-akor yang sama.

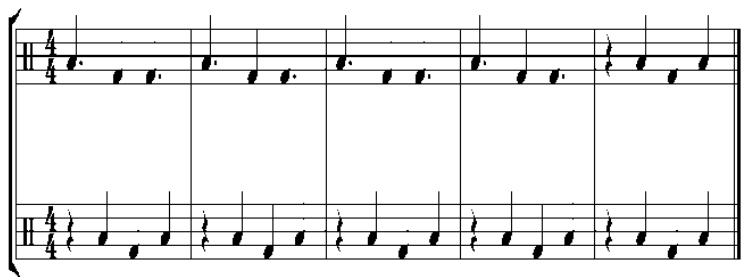

Bentuk lagu pada musik ini terdiri dari dua anak kalimat atau frase, yaitu kalimat pertanyaan dan jawaban. Kalimat pertanyaan biasanya berhenti mengambang, maka dapat dikatakan berhenti dengan koma. Sedangkan kalimat jawaban merupakan jawaban atau lanjutan dari kalimat pertanyaan dan berhenti dengan titik. Kemudian untuk memperlihatkan bentuk musik, maka ilmu bentuk musik memakai sejumlah kode untuk kalimat atau periode pada umumnya dipakai huruf besar (A,B,C, dan sebagainya). Pada masa sekarang ini lagu-lagu yang ada memiliki banyak bagian intro, bait, reff, interlude, chorus, dan ending tetapi untuk kalimat atau periode yang digunakan oleh Grup Paguyuban Kesenian Kuda Lumping hanya menggunakan huruf A dan B yang terdiri dari kalimat pertanyaan dan kalimat jawaban.

\section{Motif}

Motif adalah bentuk pola irama dan melodi yang pendek tetapi mempunyai arti. Motif berguna memberikan arah tertentu pada melodi yang memberi hidup pada suatu komposisi.

a). Motif 1

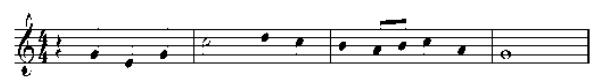

b). Motif 2

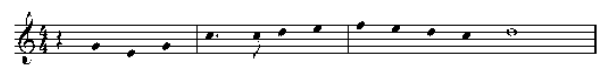

Dari motif tersebut dikembangkan akan membentuk Frase.

\section{Frase}

Frase ialah bagian dari kalimat musik yang merupakan pengembangan Motif. Frase terbentuk dari pengembangan Motif yang membentuk suatu pola irama tertentu dalam lagu.pada Musik Iringan Kesenian Tradisional Kuda Lumping bagian A, dari motif 1 dan motif 2, setelah dikembangkan terbentuk Frase berikut:

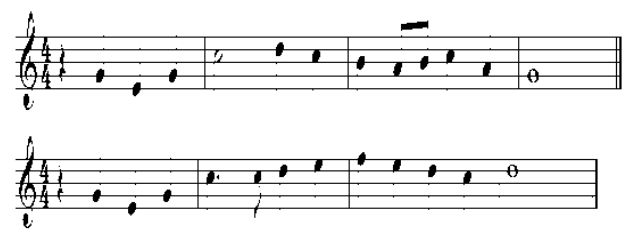

\section{Kalimat Musik}

Kalimat musik adalah bagian dari lagu yang merupakan gabungan dari Phrase. Kalimat musik pada Komposisi Musik Iringan Kesenian Tradisional Kuda Lumping bagian A, terdiri dari Motif 1, motif 2, motif 3 yang dikembangkan menjadi 1 (Satu) frase dan sehingga menjadi lagu bagian $B$
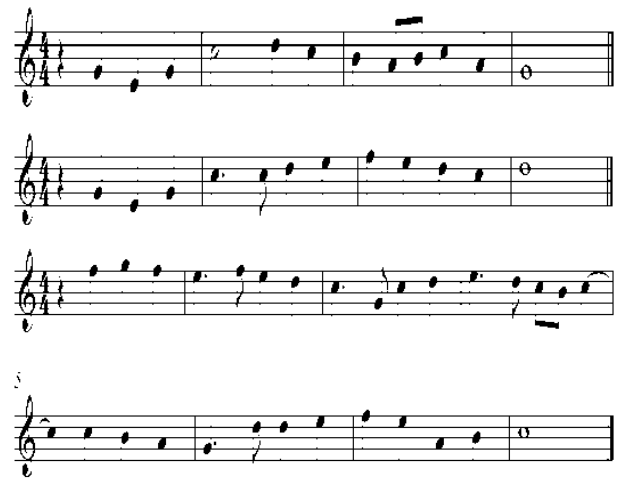

Komposisi lagu yang dimainkan Grup Paguyuban Kuda Lumping semuanya 
memiliki tempo yang sama, yaitu tempo moderato: sedang yaitu sekitar 95-104. hal ini dapat dilihat dari pola iringan tiap-tiap instrument dalam mengiringi setiap lagu. Temponya tergolong sedang, tidak terlalu cepat dan tidak terlalu lambat, dan setiap akan masuk kebagian refren lagu pola iringan dari instrument musikknya dibunyikan dengan dinamika lebih menghentak-hentak, sedangkan pada akhir lagu temponya semakin pelan dan diakhiri dengan bunyi hentakan dari empat buah terbang kencer.

Dinamika yang terjadi pada iringan kesenian tradisonal kuda lumping di saat awal lagu dinamika yang digunakan dengan dinamika lembut kemudian dipertengahan lagu dinamika yang digunakan dinamika agak keras kemudian diakhir lagu dinamika yang digunakan kembali menggunakan dinamika lembut kemudian diakhiri dengan hentakan nada terakhir dibarengi oleh semua pengiring musik Kesenian Tradisional Kuda Lumping.

Ekspresi dalam musik adalah ungkapan pikiran dan pikiran manusia yang mencakup semua nuansa dari tempo, dinamik, dan warna nada dari unsur pokok musik, dalam pengelompokan frase (phrasring) yang diwujudkan oleh seniman musik atau penyanyi yang disampaikan kepada pendengarnya (Jamalus, 1988:38).

Instrumen yang digunakan untuk mengiringi Kesenian Tradisional Kuda Lumping di Dukuh Tegallaos ini yaitu terdiri dari empat buah alat musik Terbang Kencer dan satu Bedug yaitu (Misan, Mindo, Mintelu, Minpat, dan Bedug). Instrument-instrumen tersebut memiliki pola irama yang berbedabeda satu dengan yang lainnya. Empat buah Terbang Kencer tersebut mempunyai bentuk dan ukuran yang sama. Alat musik tersebut bentuknya bundar menyerupai piring yang bagian alasnya terbuka. Permukaan bagian atasnya bergaris tengah sekitar 40 centimeter. Pada badan terbang yang semakin ke bawah semakin kecil itu ada tiga lubang yang berukuran tinggi 1 centimeter dan panjang 11 centimeter dengan posisi mendatar. Jarak antara lubang yang satu dengan lubang yang lainnya sama. Bedug adalah alat musik tabuh seperti tabuh seperti kendang, bedug merupakan instrument musik tradisional yang telah digunakan sejak ribuan tahun lalu, yang memiliki fungsi sebagai alat komunikasi tradisional, baik dalam kegiatan ritual keagamaan maupun politik.

Di dalam permainan terbang kencer bedug berfungsi sebagai pengatur ritmis sebuah pola iringan dari semua alat musik terbang kencer itu sendiri. Di sisi lain juga sebagai iringan atau sebuah ketukan tempo bagi terbang kencer, bedug dimainkan sesuai dengan pola iringan yang sudah di tentukan. Cepat,lambat,keras dan pelannya sebuah musik terbang kencer di atur oleh bedug itu sendiri sehingga permainnya memiliki dinamika yang sangat teratur.

c). Syair lagu yang dinyanyikan

Lagu adalah rangkaian nada atau melodi yang disertai syair yang dibawakan oleh Grup Paguyuban kesenian Kuda Lumping. Lagu-lagu yang dibawakan Grup Paguyuban Kuda Lumping adalah lagu-lagu Sholawat. Lagu-lagu tersebut berisi pujipujian doa, sholawat, serta naseha-nasehat agama. Contoh beberapa lagu yang dibawakan dalam Kesenian Rebana Grup Paguyuban Kuda Lumping antara lain sebagai berikut :

a. Sholawat Nabi

b. Syairan/Sisindiran

Dibawah ini contoh syair lagu yang dibawakan dalam musik Rebana Terbang Kencer dalam Grup Paguyuban Kuda Lumping:

\section{Sholawat Nabi}

Allahumma sholliwasalim 'ala Sayyidina wamaulana muhammadin 'Adada ma fi' ilmillahisholatan

Daimatan bidawami mulkillahi

Ayo sadulur lanang wadon kabeh bae (ayo saudara ku laki-laki dan perempuan semuanya)

Susah seneng aja tinggal ibadahe 
(susah dan seneng jangan meninggalkan ibadahnya)

Harta benda ora dadi jaminane

(harta dan benda tidak menjadi jaminan)

Ning akhirat mung di itung pahalane

(diakhirat yang di hitung hanya pahalanya)

\section{Syairan/sisindiran}

Bintang lima

Kanan kiri burung dara

Ayo rakyat pada bersama

Pancasila dasar Negara

Ana motor mangan mobil

(ada motor makan mobil)

Gorengane kapal udara

(gorengannya kapal udara)

Ora di senggolora di jawil

(tidak di senggol dan tidak di sentuh)

Kemutan badan sengsara

(inget badans edang sengsara)

Ijo-ijo godong rambutan

(hijau-hijau daun rambutan)

Godonge ijo di pangan wedus

(daunya hijau di makan kambing)

Bocah brondong nganggo rebutan

(anak muda jadi rebutan)

Barang di bojoora tau adus

(setelah di jadikan suami tidak pernah mandi)

\section{Aspek Penyajian Kesenian Tradisional Kuda Lumping}

Suatu rangkian kegiatan pertunjukan seni tentu memiliki urutan dan berbagai persiapan yang berhubungan dengan pementasanya. Dari hasil observasidi lapangan dirumuskan bahwa bentuk pertunjukan musik Rebana Terbang Kencer dalam Kesenian Kuda Lumping meliputi beberapa unsur yaitu : urutan penyajian, waktu, tata panggung, tata suara, pemain musik, penyanyi, tata rias, tata busana, tata lampu, dan formasi pertunjukan.

Urutan penyajian grup musik Rebana Terbang Kencer tidak langsung pada acara protokoler, artinya dipandu langsung oleh pembawa acara atau MC (Master of Ceremony) bagian demi bagian disajikan,bagian demi bagian disajikan. Sebelum acara pertunjukan dimulai, crew lapangan memberitahukan kepada pemandu untuk menyiapkan segala sesuatu yang berhubungan dengan sound system. Pemandu dan dibantu crew lapangan mengecek seluruh alat yang akan digunakan dalam pertunjukan, Setelah persiapan dilanjutkan pembukaan, yaitu pada waktu pembukaan semua alat musik tidak ada yang dimainkan, karena sebelum acara inti dimulai didahului dengan acara pembukaan yang disampaikan oleh pemimpin musik Rebana Terbang Kencer dari Paguyuban Kesenian Kuda Lumping. Pembukaan biasanya pemandu acara memberi tahu kepada penonton tentang aturan agar tidak dilanggar. pembukaan selesai, selanjutnya pertunjukan inti. Sebelum masuk ke acara inti, pawang mulai bersiap untuk memanggil roh menggunakan bacaan mantra pemanggilan roh. musik mulai dimainkan diiringi dengan nyanyian Sholawatan dan pawang mulai memasukkan roh kepada para pemain Kesenian Kuda Lumping satu persatu, para pemain yang sudah kemasukan roh mulai menari sesuai dengan iringan musik Rebana Terbang Kencer yang dimainkan beserta nyanyian Sholawat. Setelah itu Kesenian Kuda Lumping berjalan mengikuti rute yang sudah ditentukan, setiap langkah pemain Kuda Lumping di awasi oleh pemandu dan pawang, disela-sela pemain jalan mengikuti rute salah satu pemain beraksi dengan mengejar salah satu penonton yang sedang merokok dan pemain Kuda Lumping langsung memukul dengan kulit Kuda Lumping. Pada acara penutup pawang mulai mengeluarkan roh, setelah para pemain Kuda Lumping sadar, musik Rebana Terbang Kencer berhenti.Pada acara penutup yaitu dengan menyampaikan permohonan maaf dan ucapan terimakasih oleh pimpinan Paguyuban Kesenian Kuda Lumping kepada para penonton.

Pertunjukan musik Rebana Terbang Kencer sebagai iringan Kuda Lumping tidak 
menuntut adanya bentuk panggung yang biasa digunakan pada acara pada umumnya melainkan pertunjukan kuda lumping disajikan dijalan raya yang sudah ditentukan rute jalan oleh tim keamanan dari hansip atau linmas. Bentuk tempat pertunjukan musik Rebana Terbang Kencer sebagai iringan Kuda Lumping menggunakan bentuk tempat terbuka, artinya penonton dapat melihat pertunjukan Rebana Terbang Kencer tersebut dari arah depan, arah samping kanan dan samping kiri. Dengan tempat terbukalah penonton dari daerah manapun bisa melihat Kesenian Kuda Lumping dengan jelas, karena kesenian ini melewati beberapa dusun yang sudah ditentukan jauh maupun dekatnya oleh panitia sampai di tempat orang yang punya hajat.

Tata suara pertunjukan musik Rebana Terbang Kencer sebagai iringan Kesenian Kuda Lumping tidak kalah penting dengan peralatan lainnya, yang didukung dengan tata suara.Pada dasarnya unsur yang cukup penting dalam suatu pertunjukan musik adalah suara atau bunyi. Pertunjukan musik Rebana Terbang Kencer sangat mempengaruhi baik atau tidaknya pertunjukan Kuda Lumping, karena musik Rebana Terbang Kencer adalah alat musik yang paling utama dalam pertunjukan Kesenian Kuda Lumping. Sebagai pendukung utama dalam tata suara yaitu toak, ampli, mic dan aki sebagai sumber listrik.

Dari pengamatan penulis, pemain pertunjukan musik Rebana Terbang Kencer dalam Kesenian Kuda Lumping terdiri dari 20 orang dengan rincian sebagai berikut : 4 orang memainkan rebana (misan, mindo, mintelu, minpat) dan setiap pemain dapat bergantian karena telah menguasai semua alat musik rebana terbang kencer, 1 orang memainkan bedug dengan 2 orang sebagai pemikul, 2 orang pemikul ampli dan aki, 1 orang pemikul toak, 1 orang sebagai penyanyi, 4 orang sebagai pelaku Kuda Lumping, dan 4 orang sebagai penjagal pemain Kuda Lumping, dan 1 orang sebagai pawang.
Berdasarkan pengamatan penulis, penyanyi adalah profesi untuk mendapatkan penghasilan.Umumnya mereka adalah warga Dukuh Tegallaos yang ikut dalam Paguyuban Kesenian Kuda Lumping dan fasih dalam membaca bahasa Arab, memiliki suara yang bagus. Penyanyi dari Kesenian Kuda Lumping terdiri dari 2 orang laki-laki, mereka bergantian dalam menyanyi.

Tata busana yang dipakai para personil kelompok Terbang Kencer yaitu memakai kaos biasa dengan dibelakang kaos didesain nama (Kesenian Kuda Lumping Dukuh Tegallaos, Desa Karang Jongkeng). Semua anggota Kesenian Kuda Lumping memakai pakaian yang sama dengan warna kaos hitam tetapi untuk celana yang dikenakan oleh kelompok Terbang Kencer dalam mengiringi Kesenian Tradisional Kuda Lumping memakai celana bebas.

Formasi adalah sususnan atau barisan pemain. Dalam penampilan kesenian terbang kencer dalam mengiringi kesenian kuda lumping, para pemain atau personil kelompok Terbang Kencer tersebut berdiri dibelakang pemain pelaku Kuda Lumping, personil kelompok Terbang Kencer membuat barisan empat sejajar dan memanjang kebelakang, kemudian dibelakangnya dilanjutkan dengan berisan kelompok sound system beserta seluruh penonton penampilan kesenian Terbang Kencer untuk mengiringi Kesenian Kuda Lumping dari Grup Paguyuban Kesenian Kuda Lumping.

\section{PENUTUP}

\section{SIMPULAN}

$\begin{array}{ccc}\text { Berdasarkan hasil penelitian } & \text { yang } \\ \text { telah dilaksanakan maka dapat }\end{array}$ dikemukakan simpulan sebagai berikut:

Kesenian musik Terbang sangat berkembang di kalangan masyarakat Dukuh Tegallaos, Desa Karang Jongkeng, Kecamatan Tonjong, Kabupaten Brebes. Kesenian musik rebana terbang kencer mempunyai daya tarik bagi masyarakat setempat. Jenis alat musik yang di gunakan yaitu alat musik ritmis 
dengan seperangkat alat perkusi rebana yang dilaksanakan dengan mengiringi Kesenian Tradisional Kuda Lumping yang berjalan mengelilingi Desa Karang Jongkeng menelusuri rute yang sudah di tentukan, kirakira 800 meter.

Alat musik yang digunakan berjumlah lima buah alat musik, terdiri atas empat buah Terbang Kencer dan satu buah Bedug yaitu, misan, mindo, mintelu, dan minpat. Jumlah keseluruhan pemain ada 20 orang. Kesenian ini dilaksanakan pada acara khitanan dan pada hari-hari besar Islam.

Musik iringan Kesenian Kuda Lumping terdiri dari dua aspek yaitu, meliputi aspek komposisi musik dan aspek penyajian. Aspek komposisi Musik Pengiring Kesenian Kuda Lumping terdiri dari ritme, melodi, harmoni, struktur bentuk analisa musik pengiring, syair, tempo, dinamika dan ekspresi, instrumen, dan aransemen. Sedangkan aspek penyajian terdiri dari urutan penyajian, tata panggung dan waktu pertunjukan, tata busana, tata suara, pemain, penyanyi dan formasi.

\section{SARAN}

Berdasarkan hasil penelitian, saran yang dapat dikemukakan khususnya kepada Grup Paguyuban Kesenian Kuda Lumping yang menggunakan Rebana Terbang Kencer sebagai iringan antara lain adalah :

Bagi pembaca, dapat dijadikan referensi untuk penelitian selanjutnya, Perlunya dukungan pemerintah daerah Kabupaten Brebes untuk mempromosikan sekaligus menjadikan kesenian Kuda Lumping yang di iringi musik rebana terbang kencer sebagai seni pertunjukan pariwisata Kabupaten Brebes, Masyarakat Kabupaten Brebes harus tetap menjaga dan mempertahankan kelestarian kesenian Kuda Lumping yang di iringi musik rebana terbang kencer sebagai salah satu local genius di daerah Kabupaten Brebes.

\section{DAFTAR PUSTAKA}

Ambarwangi, S., \& Suharto, S. (2014). REOG AS MEANS OF STUDENTS' APPRECIATION AND CREATION IN ARTS AND CULTURE BASED
ON THE LOCAL WISDOM. Harmonia: Journal Of Arts Research And Education, 14(1), 37-45. doi:http://dx.doi.org/10.15294/harmo nia.v14i1.2789

Maryono, -. (2011). REOG KEMASAN

SEBAG AIASET PARIWISATA

UNGGULAN KABUPATEN

PONOROGO (The Packes Reog as the high tourism ofPonorogo residence). Harmonia: Journal Of Arts Research And Education, 8(2). doi:http://dx.doi.org/10.15294/harmo nia.v8i2.788

Arikunto, Suharsini. 1998. Prosedur Penelitian Suatu Pendekatan Praktik. Jakarta: Renika Cipta.

Bastomi, suwaji. 1988. Apresiasi kesenian tradisional. Semarang: IKIP Semarang Press. 1992. Wawasan Seni. Semarang: IKIP Semarang Press

Banoe, Pono. 2003. Kamus Musik. Yogyakarta: Kanisius.

Jamalus. 1988. Pelajaran Musik Melalui Pengalaman Musik. Jakarta: Depatemen Pendidikan dan Kebudayaan. Direktorat Jendral Pendidikan Tinggi. LPTK.

-1988. Pengajaran Seni Musik Melalui pengalaman musik. Jakarta : Depdikbud

Jazuli, M. 1994. Telaah Teoritis Tari. Semarang: IKIP Semarang Press.

2001. Diktat Teori Kebudayaan. Semarang: Sendratasik Unnes.

Khayam, Umar. 1981. Seni, Tradisi, Masyarakat. Jakarta: Sinar Harapan

Haviland, W.A. 1999. Antropologi Terjemahan: R.G. Soekadijo. Jakarta: Erlangga.

Margono, S. 2003. Metodologi Penelitian Pendidikan. Jakarta: Rineka Cipta.

Masunah, J dan Nara Wati. 2003. Seni dan Pendidikan Seni (Sebuah Bungarampai). Bandung: P4ST UPI.

Moleong, Lexy J. 2009. Metodologi Penelitian Kualitatif. Bandung: PT Remaja Rosdakarya.

Miller, Hugh M. 2001. Apresiasi Musik. Yogyakarta: Yayasan Lentera Budaya.

Mugiarto, Sal. 1995. Cakrawala Pertunjukan Budaya Mengkaji Batas-batas Arti Pertunjukan. Yogyakarta: Jurnal MSPI.

Napsirudin. 1996. Pelajaran pendidikan Seni. Jakarta : Yudistira. 
Negara, Insani Yodha. 2009. Bentuk dan Fungsi Pertunjukan Musik Terbang Kencer dalam Arakarakan Temanten Tebu di Desa Pangkah, Kecamatan Pangkah, Kabupaten Tegal. Skripsi. Jurusan Pendidikan Seni Musik,

Fakultas Bahasa dan Seni, Universitas Negeri Semarang.

Nurdayati, Shofiyah. 2015. Bentuk Pertunjukan Kesenian Rebana Nurul Jannah di Desa Tireman Kecamatan Rembang Kabupaten Rembang. Skripsi. Jurusan Pendidikan Seni Musik, Fakultas Bahasa dan Seni, Universitas Negeri Semarang

Pasaribu, Amir. 1986 Analisis Musik Indonesia. Jakarta: PT. Pantja Simpati.

Patton, Michael Quinn. 1987. Qualitative Evaluation Methods. Beverly Hills: Sage Publications.

Poerwadarminta, W.J.S, 1984. Kamus bahasa Indonesia. Jakarta : Balai Pustaka.

Prestisa, Galuh. 2013. Bentuk Pertunjukan dan Nilai Estetis Kesenian Terbang Kencer pada Grup Baitussolikhin di Desa BumiJawa Kecamatan Bumijawa Kabupaten Tegal. Skripsi. Jurusan Pendidikan Seni Musik, Fakultas Bahasa dan Seni, Universitas Negeri Semarang.

Purwadarminta, W.J.S, 1984. Kamus bahasa Indonesia. Jakarta : Balai Pustaka.

Rochaeni, Eni, 1989. Seni Musik 3. Bandung : Ganeca exact.

Rohidi, Tjejep rohendi, 2000. Kesenian dalam pendekatan kebudayaan. Bandung : STSI Bandung Press.

-1987. Peranan Pendidikan Kesenian dalam rangka Pengembangan Kebudayaan Nasional. Makalah disampaikan pada seminar Dosen Program Studi dan Guru Seni SLTA di IKIP Semarang

Soedarsono, R.M. 2003. Seni Pertunjukan dari Perspektif Politik, Sosial, dan Ekonomi. Yogyakarta: Gadjah Mada University Press.

Soeharto, 1992. Kamus Musik. Jakarta : PT. Gramedia.

Sedyawati, Edi. 1980. Pertumbuhan Seni Pertunjukan. Jakarta: Pustaka Sinar Harapan. --(1981). Pertumbuhan Seni Pertunjukan. Jakarta: Sinar Harapan.
Sugiyono. 2011. Metode Penelitian Kuantitatif, Kualitatif dan $R \& D$. Bandung: Alfabeta.

Wiyoso, J. (2012). KOLABORASI ANTARA JARAN KEPANG DENGAN CAMPURSARI: SUATU BENTUK PERUBAHAN KESENIAN TRADISIONAL. Harmonia: Journal Of Arts Research And Education, 11(1). doi:http://dx.doi.org/10.15294/harmonia.v1 $1 \mathrm{i} 1.1497$

Wiyoso, J. (2013). MOTIVASI MASUKNYA CAMPURSARI KE DALAM PERTUNJUKAN JARAN KEPANG. Harmonia: Journal Of Arts Research And Education, 12(1). doi:http://dx.doi.org/10.15294/harmonia.v1 2i1.2217

Sudarsono. GARAP LAKON KRESNA DHUTA DALAM PERTUNJUKAN WAYANG KULIT PURWA GAYA SURAKARTA KAJIAN TEKTUAL SIMBOLIS. Harmonia: Journal of Arts Research and Education, [S.I.], v. 12, n. 1, Jan. 2013. ISSN 2541-2426. Available at: <https://journal.unnes.ac.id/nju/index.php/h armonia/article/view/2220>. Date accessed: 20 Sep. 2017. doi:http://dx.doi.org/10.15294/harmonia.v1 2i1.2220.

Sumaryo, L.E, 1987. Komponis, Pemain Musik. Jakarta : Pustaka Jaya.

Sumaryanto, Totok. 2002. Paparan Perkuliahan Mahasiswa Penelitian Pengajaran. Semarang: Sendratasik Unnes.

2014. Metodologi Penelitian Kualitatif Untuk pendidikan Seni. Semarang: Fakultas Bahasa dan Seni.

Susetyo, Bagus. 2009. Kajian Seni Pertunjukan. Buku Ajar. Semarang: PSDTM Universitas Negeri Semarang.

Syah Sinaga, Syahrul. 2006. Fungsi dan Ciri Khas Kesenian Rebana di Pantura Jawa Tengah. Jurnal Harmonia. Vol. VII No.3 / September-Desember 2006. Semarang: Sendratasik UNNES. 
